Отримано: 12 липня 2018 р.

Прорецеензовано: 19 липня 2018 р.

Прийнято до друку: 27 липня 2018 р.

e-mail: levitska.svitlana@yahoo.com

nisushko@ukr.net

DOI: $10.25264 / 2311-5149-2018-10(38)-117-123$
Левицька С. О., Сушко Н. І. Облікове забезпечення переоцінки запасів закладами вищої освіти державної форми власності. Наукові записки Національного університету «Острозька академія». Серія «Економіка» : науковий журнал. Острог : Вид-во НаУОА, вересень 2018. № 10(38). С. 117-123.

Левицька Світлана Олексіївна,

доктор економічних наук, професор, професор кафедри обліку і аудиту

Національного університету водного господарства та природокористування

Сушко Наталія Іванівна,

кандидат економічних наук, доиент, завідувач відділу методології бухгалтерського обліку

Науково-дослідного фінансового інституту Державної навчально-наукової установи «Академія фінансового управління»

\title{
ОБЛІКОВЕ ЗАБЕЗПЕЧЕННЯ ПЕРЕОЦІНКИ ЗАПАСІВ ЗАКЛАДАМИ ВИЩОЇ ОСВІТИ ДЕРЖАВНОЇ ФОРМИ ВЛАСНОСТІ
}

Стаття присвячена обліку переочінки запасів державних закладів вищої освіти за результатами впровадження Національних Положень (стандартів) бухгалтерського обліку в державному секторі. Мета дослідження полягає у визначенні й обтрунтуванні особливостей методики переоцінки запасів протягом терміну їх балансового обліку на прикладі державних закладів вищої освіти. Запропоновано уточнення окремих положень нормативного регулювання облікових прочееур щчодо питань визначення чистої вартості реалізації запасів та ії обтрунтування.

Наведено особливості розрахунку чистої вартості реалізації запасів за принципами міжнародних стандартів бухгалтерського обліку для державного сектору. Запропоновано альтернативи щьодо застосування наведених підходів в обліковій практииі вітчизняних державних закладів вищої освіти. Визначено проблемні питання документування облікових процедур проведення переоиінки залишків запасів на дату звітності. Розкрито доцільність визначення чистої вартості реалізачії запасів із використанням ринкової вартості аналогів для забезпечення достовірності такої оцінки, щзо уможливлює дотримання принцииів Бюджетного кодексу України в питаннях раціонального та иільового використання бюджетних коштів. облік.

Ключові слова: державний заклад вищої освіти, запаси, чиста вартість реалізації, переоцінка, бухгалтерський

Левицкая Светлана Алексеевна,

доктор экономических наук, професор, професор кафедри учета и аудита

Национального университета водного хозяйства и природопользования

Сушко Наталия Ивановна,

кандидат экономических наук, дочент, заведующий отделом методологии бухгалтерского учета

Научно-исследовательского финансового института Государственной учебно-научного учреждения

«Академия финансового управления»

\section{УЧЕТНОЕ ОБЕСПЕЧЕНИЕ ПЕРЕОЦЕНКИ ЗАПАСОВ ВУЗАМИ ГОСУДАРСТВЕННОЙ ФОРМЫ СОБСТВЕННОСТИ}

Статья посвящена учету переоценки запасов бюджетных учреждений по результатам внедрения национальных положений (стандартов) бухгалтерского учета в государственном секторе. Цель исследования заключается в определении и обосновании особенностей методики переоценки запасов в течение срока их балансового учета на примере государственных учреждений высшего образования. Предложено уточнение отдельных положений нормативного регулирования учетных процедур по вопросам определения чистой стоимости реализации запасов, ее обоснование.

Приведены особенности расчета чистой стоимости реализаџии запасов согласно принципов международных стандартов бухгалтерского учета для государственного сектора. Раскрыты альтернативы применения указанных подходов в учетной практике отечественных государственных учреждений высшего образования. Определены проблемные вопросы документирования учетных процедур переоценки остатков запасов на дату отчетности. Раскрыто иелесообразность определения чистой стоимости реализации запасов с использованием рыночной стоимости аналогов для обеспечения достоверности такой оценки, что обеспечивает соблюдение принципов Бюджетного кодекса повопросам рационального и иелевого использования бюджетных средств.

Ключевые слова: государственное учреждение высшего образования, запасы, чистая стоимость реализации, переоценка, бухгалтерский учет.

Svitlana Levytska,

Doctor of Economics, Associated Professor at the Department of Accounting and Auditing,

National University of Water and Environmental Engineering 


\author{
Nataliia Sushko, \\ PhD in Economics, assistant professor, head of the Accounting methodology department \\ Research financial institute of the State educational and scientific establishment "The Academy of Financial Management»
}

\title{
ACCOUNTANCY OF REEVALUATION OF THE STOCKS FOR BUDGET INSTITUTIONS OF HIGHER EDUCATION
}

The article is devoted to the accounting of stocks by the budget institutions and bases on the results of the implementation of the National Public Sector Accounting Standards. The aim of the research is to determine and substantiate the features of the stock reevaluation methodology for the higher education institutions during the period of their accounting. It is proposed to clarify certain provisions of accounting procedures normative regulation in the process of determining the net realizable value of inventories. Carrying amount of inventories is the value at which stocks are included in the balance sheet, that is recognized alternatively by original, restorative (revalued) and fair value (depending on the nature of the previous transactions). Original cost of inventories is the value of inventories at the time of posting, which is identified as the cost of purchased inventories, the cost of the manufactured inventory, the fair value of the inventories that are received on a royalty-free basis. Revalued cost is the current cost of purchased inventories (their revalued value). Fair value is the cost of inventories that are received free of charge by the institution of higher education (from the supplier, benefactor / patron in the process of economic activity) and determined at the level of existing market prices for similar stocks. The discrepancy between the conditions of the recognizing a net realizable value of inventories taking into account financing the activities of higher education institutions is studied. There is a clear status of procurement regulation for budget institutions (including higher education institutions). Procurements are based on their value (in most cases, the smallest from offered by the suppliers), on the reputation of the supplier, acceptable terms of the delivery. As a result, the non-active market is not considered for the stock of higher education institutions (that is planned for purchasing). Taking into account the above, the organization of carrying out calculations of the balance of reserves of budgetary institutions on the reporting date is specified. Peculiarities of determining the net realizable value of inventories according to the principles of international accounting standards for the public sector are revealed, as well as the alternatives to the application of the mentioned approaches in the accounting practice of domestic state institutions of higher education.

The problematic issues of documenting transactions of the book value for stocks in the cases are determined: their receipt without payment to the supplier, the revaluation of balances of stocks at the balance sheet date. Certain procedures for determining the net realizable value of inventories are proposed, using the data on the market value of analogues in order to ensure the reliability of the valuation (which contributes to the principles of rational and targeted use of budget funds spent on the purchase of material resources of budgetary institutions).

The results of the study will ensure both reliability and objectivity of the accounting information on the indicators of stocks in the forms of financial reporting. They will increase the functional role of professional judgment, objectivity of data on the need for state financing of operations with stocks too.

Key words: budgetary institutions, stocks, net realizable value, revaluation, accountancy.

Постановка проблеми. Державні вузи - це вищі навчальні заклади III-IV рівнів акредитації, неприбуткові організації з ознакою неприбутковості 0014 [1]. Враховуючи уточнення дефініцій Законом України «Про освіту», статус державних вузів сьогодні визначають як заклад вищої освіти державної форми власності (далі - заклад вищої освіти, 3ВО).

Один із визначальних напрямів розвитку господарської діяльності закладів вищої освіти - забезпечення раціонального, цільового використання бюджетних коштів, розвиток платних освітніх послуг на конкурентних засадах. Задля підвищення ефективності управлінських рішень 3ВО необхідно реформувати всю систему бухгалтерського обліку та фінансової звітності шляхом запровадження НП(С)БОДС, розроблених на виконання стратегічних документів Уряду, таких як: Стратегія модернізації системи бухгалтерського обліку в державному секторі на 2007-2015 роки [2], Стратегія розвитку системи управління державними фінансами [3] на основі міжнародних стандартів бухгалтерського обліку в державному секторі (МСБОДС). 31 січня 2015 року розпорядниками коштів загалом і ЗВО зокрема розпочато поетапне запровадження НП(С)БОДС [4, с. 64].

За результатами впровадження Стратегії модернізації системи бухгалтерського обліку в державному секторі економіки України змінено методику обліку запасів бюджетних установ (зокрема, запасів 3ВО). Базовими нормативними документами 3 питань методології формування в бухгалтерському обліку та фінансовій звітності операцій із запасами є: НП(С)БОДС 123 «Запаси» [5], НП(С)БОДС 101 «Подання фінансової звітності» [6], НП(С)БОДС 125 «Зміни облікових оцінок та виправлення помилок» [7], Методичні рекомендації з бухгалтерського обліку запасів суб’єктів державного сектора № 11 [8] та ін.

Аналіз останніх досліджень і публікацій. Облік запасів бюджетних установ розглянуто у працях вітчизняних учених і практиків П. Й. Атамаса [9], Н. В. Артеменко [10], Л. В. Гізатуліної [11], О. О. Дорошенко [12], О. П. Куценко [11], О. О. Осадчої [13], С. В. Свірко [14] та ін.

Встановлення об'єктивної оцінки запасів на дату балансу в сучасних умовах ведення господарської діяльності державних вищих навчальних закладів потребує більшої деталізації Національними положеннями (стандартами) в державному секторі з урахуванням особливостей нормативного регулювання та системного контролю за цільовим використанням бюджетних коштів. 
Метою статті є визначення проблемних питань щодо впровадження модернізованих положень бухгалтерського обліку переоцінки запасів бюджетних установ на прикладі державних закладів вищої освіти, обгрунтування альтернативних напрямів їх вирішення.

Основні результати дослідження. 3 метою виявлення проблемних питань, пов'язаних із обліком запасів за новою методологією, доцільно розглянути стан запасів за даними консолідованої фінансової звітності Міністерства освіти і науки України (далі - МОН).

За результатами проведеного аналізу балансової вартості запасів станом на 01.01 .2018 р. за даними консолідованої фінансової звітності Міністерства освіти і науки України (далі - МОН) (Балансу за 2017 рік, форма № 1-дс) можна констатувати, що їх обсяг становить 976 млн грн (зменшився до початку звітного періоду на 17\%). Вказані форми № 5-дс вказують на те, що на звітну дату найбільшу частку у структурі запасів МОН займають групи «Малоцінні та швидкозношувані предмети» $(28,42 \%)$ та «Будівельні матеріали» $(20,76 \%)[15]$.

Варто зазначити, що у 2017 році зазнала змін класифікація запасів за планом рахунків. Так, для узагальнення інформації про надходження, рух і вибуття запасів відтепер виділено три рахунки (з поділом на окремі субрахунки), які належать до «Нефінансових активів» - клас 1 . Для бухгалтерського узагальнення запасів із 1 січня 2017 року слід застосовувати субрахунки таких рахунків: 15«Виробничі запаси»; 17 «іологічні активи» (тільки поточні біологічні активи); 18«Інші нефінансові активи» [16].

Прикладне застосування запасів у діяльності ЗВО обумовлює потребу в уточненні функціонального призначення запасів відповідно до варіативних статей попередньо затвердженого кошторису витрат в розрізі загального та спеціального фондів фінансування діяльності закладу. Як альтернатива, запаси - це активи, що, зокрема: використовуються для споживання, безоплатного розподілу, передачі в умовах операційної діяльності з метою виконання статутних завдань; перебувають у формі сировини чи допоміжних матеріалів, необхідних для операцій з надання освітніх та інших послуг, у виробництві продукції, під час виконання робіт; утримуються для подальшого продажу.

Зазначимо, що у наведеному в НП(С)БОДС 123 визначенні запасів тривалість використання не $\epsilon$ їх ключовою відмінністю від інших активів (п.4, р. 1НПСБОДС 123), що не суперечить міжнародній практиці визнання нефінансових активів.

Балансова вартість запасів - вартість, за якою запаси долучають до підсумку балансу, що, залежновід характеру попередніх операцій, визнають альтернативно за первісною, відновлювальною (переоціненою) та справедливою вартістю.

Первісна вартість запасів - вартість запасів у момент оприбуткування, що ідентифікується як: собівартість придбаних запасів, собівартість виготовлених запасів, справедлива вартість одержаних запасів на безоплатній основі.

Відновлювальна вартість - сучасна собівартість придбаних запасів (іх переоцінена вартість) .

Справедлива вартість - вартість запасів, отриманих закладом вищої освіти безоплатно (від постачальника, благодійника / мецената в процесі господарської діяльності), визначена на рівні існуючих ринкових цін на аналогічні запаси.

Розглянемо відмінність в облікових підходах у визначенні первісної та відновлювальної вартості (таблиця 1).

НП(С)БОДС 123 (розділ «Оцінка запасів на дату балансу») уточняє умови застосування чистої вартості реалізації: «Запаси відображаються за чистою вартістю реалізації, якщо на дату балансу їх ціна знизилась, вони зіпсовані, застаріли або по-іншому втратили первісно очікувану економічну вигоду». Очевидно йдеться про уцінку. Однак у наступних пунктах згаданого стандарту йдеться про збільшення вартості запасів: «Якщо чиста вартість реалізації тих запасів, що раніше були уцінені та $є$ активами на дату балансу, надалі збільшується, то на суму збільшення чистої вартості реалізації, але не більше суми попереднього зменшення, визнається дохід із збільшенням вартості цих запасів» (п. 5 розд. III «Оцінка запасів на дату балансу» НП(С)БОДС 123) [5].

Із наведеного слідує: модернізований облік запасів закладів вищої освіти регулює підходи як уцінки, так і дооцінки, тобто запаси протягом терміну їх балансового утримання можуть переоиінювати.

Чиста вартість реалізації запасів - очікувана ціна реалізації запасів в умовах звичайної діяльності, за вирахуванням очікуваних витрат на завершення їх виробництва та реалізацію (п. 4 розд. I «Загальні положення» НП(С)БОДС 123). Виникає практичне запитання: які критерії є достатніми для впевненості, що очікувана ціна (очікувані витрати) встановлено правильно?

Аналогічні питання також щодо визначення справедливої вартості. Нормативна облікова база не містить чіткості в регламентації відмінностей між справедливою вартістю та чистою вартістю реалізації: справедлива вартість - це вартість, визначена суб'єктом господарювання, чиста вартість реалізації - чиста сума, яку заклад вищої освіти очікує отримати від продажу запасів (отже, може не дорівнювати справедливій вартості за мінусом витрат на продаж). 
Оцінка запасів державних закладів вищої освіти на дату звітності

\begin{tabular}{|c|c|c|c|}
\hline \multirow[b]{2}{*}{$\begin{array}{l}\text { № } \\
\text { 3\III }\end{array}$} & \multirow[b]{2}{*}{ Характер операції із запасами } & \multicolumn{2}{|c|}{$\begin{array}{l}\text { Регламентування } \\
\text { класифікації }\end{array}$} \\
\hline & & 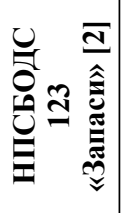 & 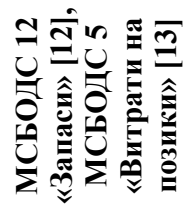 \\
\hline 1 & 2 & 3 & 4 \\
\hline 1. & \multicolumn{3}{|l|}{ Первісна вартість запасів (у момент їх оприбуткування на балансовий облік) } \\
\hline \multirow{4}{*}{1.1.} & $\begin{array}{l}\text { Собівартість оприбуткування запасів, одержаних від постачальника на умовах розра- } \\
\text { хунку, включає ціну придбання, мито, інші податки (крім тих, що повертаються суб'єкту), } \\
\text { а також інші витрати, безпосередньо пов'язані з операцією придбання. }\end{array}$ & $\mathrm{V}$ & \\
\hline & Торговельні знижки, інші знижки вираховуються від вартості придбання (МСБОДС 12). & & $\mathrm{V}$ \\
\hline & За певних обставин витрати на позики включаються до собівартості запасів (МСБОДС 5). & & $\mathrm{V}$ \\
\hline & $\begin{array}{l}\text { Включення транспортно-заготівельних витрат до первісної вартості видів запасів при їх } \\
\text { оприбуткуванні: у випадку достовірного визначення суми таких витрат - безпосередньо } \\
\text { відносяться до придбаних запасів; якщо транспортно-заготівельні витрати пов'язані із } \\
\text { доставко кількох найменувань - їх сума може узагальнюватися за окремими групами } \\
\text { запасів на окремому субрахунку (аналітичному рахунку). }\end{array}$ & $\mathrm{V}$ & $\mathrm{V}$ \\
\hline 1.2. & $\begin{array}{l}\text { Cобівартість виготовлених запасів (готової продукції) містить прямі виробничі та розпо- } \\
\text { ділені загальновиробничі витрати. }\end{array}$ & $\mathrm{V}$ & $\mathrm{V}$ \\
\hline \multirow[t]{3}{*}{1.3 . } & Справедлива вартість безоплатно одержаних запасів. & & \\
\hline & $\begin{array}{l}\text { Балансова вартість отриманих безоплатно запасів: від фізичних та юридичних осіб (крім } \\
\text { суб'єктів державного сектору) - їх справедлива вартість, щодо якої є достовірна інфор- } \\
\text { мація; від суб'єктів державного сектора - балансова вартість запасів суб'єкта державного } \\
\text { сектора, що їх передав, з урахуванням витрат, пов'язаних з операцією прибуткування. }\end{array}$ & $\mathrm{V}$ & \\
\hline & $\begin{array}{l}\text { Балансова вартість отриманих безоплатно запасів від суб'єктів державного сектора - } \\
\text { балансова вартість запасів суб 'єкта державного сектора, щю їх передав, з урахуванням } \\
\text { витрат, пов'язаних з операцією прибуткування. }\end{array}$ & $\mathrm{V}$ & \\
\hline 2. & \multicolumn{3}{|l|}{ Відновлювальна вартість запасів (вартість після переоцінки). } \\
\hline \multirow{3}{*}{2.1 . } & $\begin{array}{l}\text { В результатів переоцінки запаси оцінюються за меншою з двох оцінок: собівартістю або } \\
\text { поточною відновлювальною собівартістю (чистою вартістю реалізації - ЧВР). }\end{array}$ & $\mathrm{V}$ & $\mathrm{V}$ \\
\hline & $\begin{array}{l}\text { Сума, на яку первісна вартість запасів перевищує їх чисту вартість реалізації списуються } \\
\text { на витрати звітного періоду. }\end{array}$ & $\mathrm{V}$ & $\mathrm{V}$ \\
\hline & $\begin{array}{l}\text { Якщо чиста вартість реалізації уцінених попередньо запасів надалі збільшується, то на } \\
\text { суму збільшення чистої вартості реалізації, але не більше суми попереднього зменшення, } \\
\text { визнається дохід із збільшенням вартості цих запасів. }\end{array}$ & $\mathrm{V}$ & $\mathrm{V}$ \\
\hline 2.2. & $\begin{array}{l}\text { Суми нестач і втрат від псування цінностей до прийняття рішення про конкретних вину- } \\
\text { ватців відображаються на позабалансових рахунках. }\end{array}$ & $\mathrm{V}$ & \\
\hline
\end{tabular}

*У таблиці узагальнено інформацію з нормативних облікових джерел $[5 ; 17 ; 18]$.

Сьогодні дооцінка запасів відповідно до норм п. 21 розд. II «Визнання та оцінка запасів» Методрекомендацій № 11 не проводиться, крім випадку передбаченого п. 20 цього розділу: «Якщо чиста вартість реалізації тих запасів, що раніше були уцінені до чистої вартості реалізації та є активами на дату балансу, надалі збільшується, але не більше суми попереднього зменшення, визнається дохід із збільшенням вартості цих запасів» [8]. Ця норма Методрекомендацій узгоджується із нормою, визначеною у п. 5 розд. III «Оцінка запасів на дату балансу» НПСБОДС 123.

Послідовність обліково-організаційних процедур по дооцінці/уцінці (далі - переоцінці) запасів закладами вищої освіти можна узагальнити наступним чином: 1 - встановлення потреби в проведенні переоцінки певного класу запасів; 2 - проведення інвентаризації запасів, що плануються для переоцінки; 3 - розрахунок суми переоцінки та оформлення результатів. Розглянемо детальніше організаційні особливості названих етапів.

1. Потребу в проведенні переоцінки певного класу запасів підтверджує обгрунтування зниження економічної вигоди/потенціалу корисності, які може одержати заклад вищої освіти за результатами використання таких запасів. Рішення про переоцінку запасів приймається керівником закладу. Враховуючи вимоги щодо документального підтвердження розрахунків, для визначення нової «реальної ціни» комісія щодо проведення переоцінки може використовувати: рахунки або накладні на отримані аналогічні матеріальні цінності, публіковані в засобах масової інформації листи підприємства-постачальника та інших 
підприємств, що випускають аналогічну продукцію, із відображенням нової ціни; ціни, встановлені в торговельній мережі на подібні товари; експертні висновки про вартість матеріальних запасів, малоцінних і швидкозношуваних предметів.

Потребують обгрунтування також ознаки зменшення корисності через зміни у використанні таких запасів. І хоча НП(С)БОДС 127 «Зменшення корисності активів» поширюється на активи, крім запасів, практично цінною може бути регламентація роботи щзодо встановлення розміру втрати корисності запасів закладів вищзӧ освіти.

Ознаки зменшення корисності запасів можна ідентифікувати за підтвердження таких умов: зменшення ринкової їх вартості протягом звітного періоду на суттєво більшу величину, ніж очікувалося; суттєві негативні зміни в технологічних, правових умовах, у яких функціонує заклад вищої освіти; зміна способу використання запасів протягом звітного періоду, або очікуються найближчим часом; старіння, фізичне пошкодження запасів; інше свідчення того, що ефективність використання запасів є, або буде значно мениою, ніж очікувалось [20].

Зазначимо, що виділені курсивом критерії зменшення корисності варто регламентувати (за зовнішніми ознаками, умовами, критеріями, діапазоном, рівнем тощо) в наказі про облікову політику закладів вищої освіти, попередньо узгодивши з головним розпорядником коштів - Міністерством освіти і науки України.

2. Інвентаризація запасів, що плануються для переоцінки, $є$ за новим Положенням про інвентаризацію «вибірковою інвентаризацією», має дотримуватись правил по проведенню інвентаризації загалом [21]. Варто мати на увазі наступні вимоги щодо підготовки інвентаризаційного опису, дотримання яких забезпечить правильний підрахунок загального розміру переоцінки: на запаси, що знаходяться в дорозі, не оплачену в термін покупцями відвантажену продукцію (товари) та на ті активи, що перебувають на складах інших суб'єктів складаються окремі інвентаризаційні описи; на кожній сторінці інвентаризаційного опису вказуються словами число порядкових номерів активів і загальна кількість у натуральних вимірах; в інвентаризаційних описах виправлення помилок повинно робитися винятково коректурним методом; інвентаризаційні описи підписуються всіма членами інвентаризаційної комісії та матеріально відповідальними особами та ін.

3. Розрахунок суми переоцінки й оформлення результатів - визначальний етап, що впливає на звітні показники закладу вищої світи.

Залежно від зовнішніх цінових факторів впливу на аналогічні активи, запаси закладів вищої світи можуть як збільшуватись у ціні, так і навпаки - зменшуватись. Однак першочерговим кроком є їх зменшення:

- крок I: запаси оцінюються на дату звітності за меншою з двох оцінок: собівартістю або поточною відновлювальною собівартістю;

- крок II: Якщо чиста вартість реалізації тих запасів, що раніше були уцінені та є активами на дату балансу, надалі збільшується, то на суму збільшення чистої вартості реалізації, але не більше суми попереднього зменшення, визнається дохід із збільшенням вартості цих запасів (п. 4-5 НП(С)БОДС «Запаси») [5].

Кореспонденції рахунків бухгалтерського обліку переоцінки запасів із використанням Плану рахунків бухгалтерського обліку в державному секторі [16]:

1. Списання суми, на яку первісна вартість запасів перевищує чисту вартість їх реалізації:

Дт8411 «Інші витрати за обмінними операціями»;

Кт15 «Виробничі запаси», 18 «ншші нефінансові активи».

2. Збільшення чистої вартості реалізації запасів, що раніше були уцінені, але не більше суми попереднього зменшення:

Дт15 «Виробничі запаси», 18 «Інші нефінансові активи»;

Кт7411 «ншідоходи за обмінними операціями».

3. Дт 073 «Невідшкодовані нестачі і втрати від псування цінностей розпорядників бюджетних коштів» - позабалансовий облік визначених збитків [18].

Приклад. Заклад вищої освіти закупив у листопаді 2018 р. 1000 упаковок канцелярського паперу собівартістю придбання 80,00 грн. за одиницю (за рахунок коштів спецфонду). На дату підготовки річної звітності за даними інвентаризації на 31.12.2018 р. залишок канцтоварів склав 600 упак. (400 упак. було списано на адміністративні потреби структурних підрозділів, які надають платні послуги), їх чиста вартість реалізації за підтвердженою документально інформацією - 70,00 грн/од. За рішенням керівництва закладу станом на 31 грудня 2018 р. проведено уцінку залишків паперу до чистої вартості реалізації. На дату підготовки звітності за I квартал 2019 р. залишок канцтоварів склав 300 упак., їх чиста вартість реалізації - 85,00 грн/од. Відповідно до НП(С)БОДС 123 та облікової політики закладу проведено дооцінку запасів до собівартості придбання - 80,00 грн (оскільки собівартість придбання, що складає 80,00 грн/ од., що є меншою від чистої реалізаційної вартості 85, 00 грн/од.). Облікове забезпечення операцій: 


\begin{tabular}{|c|c|c|c|c|}
\hline \multirow{2}{*}{$\begin{array}{l}\text { № } \\
\text { 3/II }\end{array}$} & \multirow{2}{*}{ Зміст операції } & \multirow{2}{*}{ Сума, грн } & \multicolumn{2}{|c|}{ Кореспондуючий рахунок [23] } \\
\hline & & & Дт & Кт \\
\hline 1 & 2 & 3 & 4 & 5 \\
\hline 1 & $\begin{array}{l}\text { Оприбутковано канцелярський папір у } \\
\text { листопаді } 2018 \text { р.(1000 упак. по 80,00 грн/ } \\
\text { од.).Оплата була проведена авансовим } \\
\text { платежем. } \\
\end{array}$ & 80000,00 & $\begin{array}{l}1812 \text { «Малоцінні та } \\
\text { швидкозношувані } \\
\text { предмети» }\end{array}$ & $\begin{array}{l}2113 \text { «Розрахунки за аванса- } \\
\text { ми, виданими постачальни- } \\
\text { кам, підрядникам за товари, } \\
\text { роботи і послуги», }\end{array}$ \\
\hline \multirow{2}{*}{2.} & $\begin{array}{l}\text { Передано в листопаді-грудні } 2018 \text { р. } 400 \\
\text { упак. паперу структурним підрозділам, що } \\
\text { надають платні послуги. Папір списано як } \\
\text { використаний відповідно до Акту }\end{array}$ & 32000,00 & $\begin{array}{l}8113 \text { «Матеріальні } \\
\text { витрати» }\end{array}$ & $\begin{array}{l}1812 \text { «Малоцінні та швидко- } \\
\text { зношувані предмети» }\end{array}$ \\
\hline & Закриття рахунків витрат & 32000,00 & $\begin{array}{l}5511 \text { «Фінансові } \\
\text { результати виконання } \\
\text { кошторису звітного } \\
\text { періоду» }\end{array}$ & 8113 «Матеріальні витрати» \\
\hline \multirow{2}{*}{3.} & $\begin{array}{l}\text { Списано на витрати уцінку до чистої } \\
\text { вартості реалізації } 70,00 \text { грн/од. } 600 \text { упак. } \\
\text { Паперу станом на } 31.12 .2018 \text { р. }(600 \\
\text { упак.х(80,00-70,00) грн/од.) }\end{array}$ & 6000,00 & $\begin{array}{l}8411 \text { «ншші витрати за } \\
\text { обмінними операці- } \\
\text { ями» }\end{array}$ & $\begin{array}{l}1812 \text { «Малоцінні та швидко- } \\
\text { зношувані предмети» }\end{array}$ \\
\hline & Закриття рахунків витрат & 6000,00 & $\begin{array}{l}5511 \text { «Фінансові } \\
\text { результати виконання } \\
\text { кошторису звітного } \\
\text { періоду» }\end{array}$ & $\begin{array}{l}8411 \text { «Інші витрати за обмін- } \\
\text { ними операціями» }\end{array}$ \\
\hline 4. & $\begin{array}{l}\text { Віднесено витрати на позабалансовий } \\
\text { рахунок * }\end{array}$ & 6000,00 & 073 & \\
\hline \multirow{2}{*}{5.} & $\begin{array}{l}\text { Передано в січні-березні } 2019 \text { р. }(600-300) \\
\text { упак. паперу балансовою вартістю } 70,00 \\
\text { грн/од. структурним підрозділам, що нада- } \\
\text { ють платні послуги }\end{array}$ & 21000,00 & $\begin{array}{l}8113 \text { «Матеріальні } \\
\text { витрати» }\end{array}$ & $\begin{array}{l}1812 \text { «Малоцінні та швидко- } \\
\text { зношувані предмети» }\end{array}$ \\
\hline & Закриття рахунків витрат & 21000,00 & $\begin{array}{l}5511 \text { «Фінансові } \\
\text { результати виконання } \\
\text { кошторису звітного } \\
\text { періоду» }\end{array}$ & 8113 «Матеріальні витрати» \\
\hline \multirow[t]{2}{*}{6.} & $\begin{array}{l}\text { Визнано станом на } 31.03 .2019 \text { р. доходи від } \\
\text { дооцінки залишку паперу до собівартості } \\
\text { придбання (300 упак. X }(80,00-70,00) \text { грн/ } \\
\text { од.) }\end{array}$ & 3000,00 & $\begin{array}{l}1812 \text { «Малоцінні та } \\
\text { швидкозношувані } \\
\text { предмети» }\end{array}$ & $\begin{array}{l}7411 \text { «нші доходи за обмін- } \\
\text { ними операціями» }\end{array}$ \\
\hline & Закриття рахунків доходів & 3000,00 & $\begin{array}{l}7411 \text { «Інші доходи за } \\
\text { обмінними операціями» }\end{array}$ & $\begin{array}{l}5511 \text { «Фінансові результати } \\
\text { виконання кошторису звітно- } \\
\text { го періоду» }\end{array}$ \\
\hline 7. & $\begin{array}{l}\text { Сторновано витрати від попередньої уцінки } \\
\text { на позабалансовому рахунку }\end{array}$ & 3000,00 & & 073 \\
\hline
\end{tabular}

*У наступному звітному році сума витрат буде передбачена в кошторисі діяльності, що фінансується коштами спецфонду.

Із метою застосування нових підходів щодо визнання,оцінки/переоцінки запасів у бухгалтерському обліку, визначених, зокрема НП(С)БОДС 123«Запаси», було запропоновано розробити Методичні рекомендаиії з бухгалтерського обліку окремих активів, зобов'язань закладів вищяої освіти [4, с. 66]. Саме в цьому документі мають міститися відповіді на всі порушені проблемні питання, які стосуються запасів.

Висновок. Отже, на основі дослідження модернізованої методики обліку запасів державних закладів вищої освіти доведено необхідність удосконалення їх відображення в системі рахунків бухгалтерського обліку, насамперед, методики визначення балансової оцінки запасів в умовах ринку, облікового забезпечення на етапах коригування вартості за критерієм «балансова вартість min чиста вартість реалізації».

Підтверджено потребу в чіткішій ідентифікації облікових процедур під час розрахунку чистої вартості реалізації, поточної відновлювальної вартості запасів; у кваліфікованому підході до розкриття професійного судження на етапах встановлення доцільності переоцінки запасів. Це забезпечить достовірність облікової інформації за показниками залишків запасів у формах фінансової звітності, надасть об'єктивні дані щодо потреби в державному фінансуванні операцій із запасами, підвищить функціональну роль професійного судження.

Вказані питання доцільно структурувати в наказі про облікову політику за погодженням із головним розпорядником коштів. 


\section{Література:}

1. Про затвердження Положення про Реєстр неприбуткових організацій та установ: наказ Міністерства Фінансів України 24.01.2013 №37. URL. [Електронний ресурс]. - Режим доступу::http://search.ligazakon.ua.

2. Про затвердження Стратегії модернізації системи бухгалтерського обліку в державному секторі на 20072015 роки : постанова Кабінету Міністрів України від 16.01.2007 № 34. URL: http://zakon5.rada.gov/ua/lavs/ show/34-2007-п.

3. Про Стратегію розвитку системи управління державними фінансами : розпорядження Кабінету Міністрів України від 01.08.2013 № 774-p. URL: http://zakon.rada. gov.ua/laws/show/774-2013-p.

4. Сушко Н. І., Даниленко С. В. Удосконалення регулювання державних видатків на послуги вищої освіти. Фінанси України. 2018. № 4 С. 56-74.

5. Національне положення (стандарт) бухгалтерського обліку в державному секторі 123 «Запаси» : затверджене наказом Міністерства фінансів України від 12.10.2010 № 1202.URL: http://zakon4.rada.gov.ua/laws/show/ z1019-10.

6. Національне положення (стандарт) бухгалтерського обліку в державному секторі 101 «одання фінансової звітності»: затверджене наказомМіністерства фінансів України від 24.12.2010 № 1629.URL:http://zakon2. rada.gov.ua/laws/show/z0087-11.

7. Національне положення (стандарт) бухгалтерського обліку в державному секторі 125 «Зміни облікових оцінок та виправлення помилок»: затверджене наказом Міністерства фінансів України від 24.12.2010 № 1629. URL: http://zakon2.rada.gov.ua/laws/show/z0087-11.

8. Методичні рекомендації з бухгалтерського обліку запасів суб'єктів державного сектору: затверджені наказом Міністерства фінансів України від 23.01.2015 № 11. URL:https:/www.buh24.com.ua/nakaz-minfinu-vid23-01-2015-11-metod-rekomendatsiyi-z-vedennya-buhobliku-zapasiv-derzh-sektoru/\#II.

9. Атамас П. Й. Облік у бюджетних установах [Електронний ресурс]. URL: http://westudents.com.ua/ knigi/50-oblk-u-byudjetnih-py.html.

10. Артеменко Н. В. Напрямки реформування бюджетного обліку [Електронний ресурc]. URL: http:// vestnik.kpi.kharkov.ua/files//2012/S16.pdf.

11. Бухгалтерський облік та внутрішній аудит у державному секторі : навч. посів. / [За заг. ред. М. В. Кужельного]. Київ. : Аграрна наука, 2009. - Ч. 3 : Бухгалтерський облік та звітність у бюджетній сфері України / Сушко Н. І., Гізатуліна Л. В., Куценко О. П. 2009. 328 с.

12. Дорошенко О. О. Запаси бюджетних установ: порівняльний аналіз сучасної облікової практики та національних положень (стандартів) бухгалтерського обліку в державному секторі. Незалежний аудитор. 2012. № 2. C. 50-54.

13. Осадча О. О. Бухгалтерський облік фінансових результатів суб'єктів державного сектора економіки України. Вісник Національного університету водного господарства та природокористування. Економіка. 2011. Вип. 2 (54). С. 157-164.

14. Свірко С. В., Осадча О. О. Доходи підприємницької та непідприємницької діяльності: визнання та облікова оцінка в умовах національних економічних реформ. Наукові записки Національного університету «Острозька академія». 2011. Вип. 18. С. 227-235.

15. Консолідований звіт МОН за 2017 рік. Офіційний сайт Міністерства освіти і науки України. URL:https:// mon.gov.ua/storage/app/media/budzhet/2018/04/03/zvit-mon-za-2017-rik.pdf.

16. Про затвердження Плану рахунків бухгалтерського обліку в державному секторі : наказ Міністерства фінансів від 31.01.2013 № 1203. URLhttp://zakon.rada.gov.ua/laws/show/z0161-14.

17. МСБОДС 12 «Запаси». URL:http://www.iasb.org.uk.

18. МСБОДС 5 «Витрати на позики». URL: http://www.iasb.org.uk.

19. Порядок дооцінки матеріальних запасів, малоцінних і швидкозношуваних предметів бюджетних установ: затверджене спільним наказом Головного управління Державного казначейства України Міністерства економіки України від 02.12.97 N127/138.

20. Національне положення (стандарт) бухгалтерського обліку в державному секторі 127 «Зменшення корисності активів»: затверджене наказом Міністерства фінансів України від 24.12.2010 № 1629. URL:http:// zakon2.rada.gov.ua/laws/show/z0087-11.

21. Положення про інвентаризацію активів та зобов'язань: затверджене наказомМіністерства фінансів України від 02.09.2014 № 879. URL: http://zakon5.rada.gov.ua/laws/show/z1365-14.

22. Про затвердження Порядку визначення розміру збитків від розкрадання, нестачі, знищення (псування) матеріальних цінностей: постанова Кабінету Міністрів України від 22.01.1996 N 116. URL:http://zakon0.rada. gov.ua/laws/show/116-96-\%D0\%BF.

23. Порядок застосування Плану рахунків бухгалтерського обліку в державному секторі: затверджений наказом Міністерства фінансів України 29.12.2015 N 1219. URL: https://buhgalter.com.ua/zakonodavstvo/ buhgalterskiy-oblik/poryadok-zastosuvannya-planu-rahunkiv-buhgalterskogo-obliku-v/. 